\title{
Simple approaches for environmental and mechanical management of the Varroa mite, Varroa destructor Anderson and Trueman (Parasitiformes: Varroidae), on the honey bee, Apis mellifera L. (Hymenoptera: Apidae) in Egypt
}

\author{
Sally F. M. Allam, Mourad F. Hassan, Ahmed S. Hassan and Mahmoud K. A. Abada*
}

\begin{abstract}
Background: Varroa mite, Varroa destructor Anderson and Trueman (Parasitiformes: Varroidae), is an ectoparasitic mite of the honey bee, Apis mellifera L. (Hymenoptera: Apidae), with a great economic importance. It is the major deadlock of apiculture development all over the world.

Results: This work aimed to assess the effect of bee house and dark bee house on numbers of Varroa mite on white card board sheets, worker broods, and alive bees during spring and autumn of 2018 and 2019. Two types of card board for sticking the fallen Varroa mite were evaluated through winter of 2019. Keeping honey bee hives in a dark room during March and September of 2018 and 2019 for a successive 3 days resulted in a great reduction in the number of Varroa inner bee hive, i.e., on the white card board sheets, area of broods, and alive honey bee. Highest number of fallen Varroa mite on the white card board sheets was obtained in the case of using the dark bee house during March and September in 2018 and 2019, followed by keeping in a normal bee house then those fallen in the case of the open apiary.

Conclusion: The dark bee house grooming behaviour increased through 3 days of dark. Environmental management of bee house and dark bee house can be promising in colony collapse disorder. Modified adhesive sheets were more efficient in this regard than the normal ones.
\end{abstract}

Keywords: Apis mellifera, Varroa destructor, Environmental management, Bee house, Grooming behaviour

\section{Background}

The ectoparasitic Varroa mite, Varroa destructor Anderson and Trueman (Acari: Varroidae), is a common devastative parasite for the honey bee, Apis mellifera L. (Hymenoptera: Apidae) causing serious losses to the beekeepers (Mabrouk et al., 2016). It feeds on the haemolymph of developing and

*Correspondence: Khairy.ebada@agri.cu.edu.eg; Dr.mkhairy89@gmail.com Department of Zoology and Agriculture Nematolology, Faculty of Agriculture, Cairo University, Giza, Egypt adult honeybees, where the infection results in carriage secondary diseases such as viral diseases (Yang and CoxFoster, 2007 and Dainat et al, 2011). Continuous chemical management can lead to emergence of real estate resistance and contaminated products. The management of Varroa mite is mostly difficult as the plurality of mites live inside the closed brood for reproduction and are well protected from the different methods of management (Kirrane et al, 2018). Photoperiod and temperature strongly influence the

\section{Springer Open}

(c) The Author(s). 2021 Open Access This article is licensed under a Creative Commons Attribution 4.0 International License, which permits use, sharing, adaptation, distribution and reproduction in any medium or format, as long as you give appropriate credit to the original author(s) and the source, provide a link to the Creative Commons licence, and indicate if changes were made. The images or other third party material in this article are included in the article's Creative Commons licence, unless indicated otherwise in a credit line to the material. If material is not included in the article's Creative Commons licence and your intended use is not permitted by statutory regulation or exceeds the permitted use, you will need to obtain permission directly from the copyright holder. To view a copy of this licence, visit http://creativecommons.org/licenses/by/4.0/. 
rate of diapause development in animals (Danks, 2002). Honeybees have a great economic importance to agriculture not only for honey production, royal jelly, pollen, propolis, pharmaceutical purposes, food production, and other industrial products (Neumann and Carreck, 2010), but also for pollination of the plants.

In most cases, acaricides are effective in managing Varroa mite, but their application within the hives mostly contaminates bees' products. In addition, the Varroa mite can develop resistance to these chemicals (Ward et al., 2008). However, there is an urgent need, for alternative, sustainable forms for its management. $V$. destructor can reproduce on both male and female brood of $A$. mellifera, thus attaining a longer reproductive season and larger mite populations. Furthermore, without managing the infested colonies with Varroa mite, they may be die within 3 years (Fries et al., 2006; Allam and Zakaria, 2009; Rosenkranz et al., 2010 and Mondet et al., 2019).

Arechavaleta-Velasco et al. (2012) reported that several mechanisms may be involved in resistance of some honey bee lines to $V$. destructor including hygienic and grooming behaviour. Grooming behaviour is one of the most important mechanisms of honey bee defence against Varroa mites, and this affected with genetic characteristics of bee colonies as well as environmental conditions (Tahmasbi, 2009). In general, Noel et al. (2020) reported that due to a short history of coevolution, the host-parasite relationship between A. mellifera and $V$. destructor is unbalanced, with honey bees suffering infestation effects at the individual, colony, and population levels.

This study aimed to test a new simple approach of managing the Varroa mites by keeping honey bee hives (colonies) in a dark bee house and also assess the effect of this trial on the colony strength.

\section{Main Text \\ Methods \\ Bee houses measurement}

Normal room measured $(3.5 \times 5.5 \times 3 \mathrm{~m})$ was built from bricks of clay and covered with 3 layers: (1) a layer from jungle with clay mixed with wheat straw, (2) a plastic sheet, and (3) a layer from jungle with clay mixed with wheat straw, in an open field at Aga county, Dakahlia governorate, Egypt. The room was named normal bee house. It has a door $(80 \mathrm{~cm}$ width $\times 1.9 \mathrm{~cm}$ height $)$ and 2 opening windows, which roll polestar and plastic wire were used to close these opening, with pores permit the bees to go in. Inner this room, another room measured $(1.8 \times 1.8 \times 2 \mathrm{~m})$. A dark room was built by the same materials but without any opening, only has a door (80 $\mathrm{cm}$ width $\times 1.9 \mathrm{~cm}$ height) to close it.
Effect of keeping colonies of honey bees in the bee houses and open apiary on the management of Varroa mite Honey colonies were divided into 3 groups, each contained of 6 hives. The first group was placed in the dark bee house, the second group was placed in the bee house, and the third group was placed in an open apiary.

\section{Effect of keeping sites of honey beehives on the mortality of Varroa mite}

The effect of keeping sites of honey bee colonies on the mortality of Varroa mites was assessed by adding a white card board sheet (coated with Vaseline), as well as counting the number of Varroa mite on random 20 broods and 100 alive bees in each hive, 3 days after placing the hives in the sites. This procedure was carried out during March (beginning of the active period of honey bees) and September (the time of high level of infection with Varroa mite) of 2018 and 2019. In addition, pure water was provided inner the dark and the normal bee house during the summer season.

\section{Assessment of the efficiency of dark bee house levels} Infestation levels in all experimental colonies were recorded after each application. The following data were recorded:

- Number of dead mites fallen down on the white card board sheet (coated with Vaseline) located under the colony

- Number of mites in random sample of 100 alive bees

- Number of mites in 20 cells of workers

The efficiency of the treatment was calculated by using the following formula of (Allam et al., 2003 and Marinelli et al., 2004):

Rate of efficiency $\%=$ No. of dead mites $/$ Total No. of mites $^{* * *} \times 100$

where "dropped mites on a white card board sheet and **:dropped mites + No. of mites on 100 alive bees + No. of mites in 20 brood cells.

\section{Effect of using modified adhesive sheets on sticking Varroa mite}

Normal adhesive sheets for mite traps (to increase the period of the validity of the used 45 sheets) or their modification by adding brood juice + royal jelly for sticking Varroa mite every 2 weeks (juice of five broods $+1 \mathrm{~g}$ royal jelly/colony) were used (to attract Varroa mite to the sheet). Due to the adhesive sheets for mite traps that have a high potential for sticking and makes bees adherent on these sheets, galvanized wire mesh was placed in each hive above the sheet to be a barrier for sticking bees on the sheet. Three hives were used for each kind 
of adhesive sheets. The experiment was carried out during September 21 to December 21 of 2019 at Dakahlia governorate, Egypt, under bee house conditions. The number of the injured and fallen Varroa mite on both kinds of the adhesive sheets (in the bottom of the hive) was counted weekly, then removed from the sheets, in each inspection, using a forceps. The averages of injured and fallen Varroa mite of each inspection were recorded.

\section{Statistical analysis}

All the data were statistically processed by split design (Snedecor and Cochran, 1980) and the analysis of variance and by determining the significance threshold using Duncan's test (Duncan, 1955).

\section{Results}

Effect of keeping colonies of honey bees in the bee houses and open apiary on the management of Varroa mite

Tables 1 and 2 show that the population of the Varroa mite was lower during March of both 2018 and 2019 than the population of September of both years. Also, the number of the fallen Varroa mite on white card board sheets was significantly higher than those found in the case of the normal bee house and the open apiary. In addition, results revealed that there were higher numbers of Varroa mite fallen on the white card board sheets as well as found on the broods and alive bees during September of both 2018 and 2019 than those found in the case of March of both years.

Data presented in Table 1 and illustrated by Fig. 1 indicated that the highest number of the fallen Varroa mites on the white card board sheets was obtained in the case of the dark bee house during March of both 2018 and 2019, being 6.2 in both years, followed by keeping in normal bee house, being 4.23 and 4.5, respectively, then those fallen in the case of the open apiary, being 2.5 and 2.8 , respectively. The same trend was found concerning the number of the Varroa mite on 20 broods and 100 alive bees.

Data shown in Table 2 and illustrated by Fig. 2 revealed that there were higher numbers of Varroa mites fallen on the white card board sheets than those fallen in the case of the normal bee house and the open apiary during September of 2018, being 24.3, 12.2, and 11.8, and being 28.2., 13.5 and 12.2 during September 2019. On the other hand, the number of Varroa mites found on 20 broods and 100 alive bees was significantly lower in the case of the dark bee house than in the normal bee house and open apiary in descending order. In this respect, the numbers of Varroa mites on 20 broods and 100 alive bees in the case of the dark bee house were 10.3 and 9.2, 22.2, and 28.2 in normal bee house and 28.5 and 48.5 in open apiary, respectively.

The obtained data revealed that there were higher numbers of Varroa mites that fallen on the white card board sheets than those fallen in the case of the normal bee house and the open apiary during September of 2018 and 2019. On the other hand, the found number of Varroa mites on 20 broods and 100 alive bees was significantly lower in the case of the dark bee house than that found in the case of the normal bee house and open apiary in descending order.

\section{Effect of using modified adhesive sheets on sticking Varroa mite}

Results shown in Table 3 revealed that the modified mite trap was more efficient than normal mite trap for sticking Varroa mites. The number of the conjoined Varroa mites was gradually increased by prolonging the period of the experiment. In addition, the modified mite trap was more efficient than the normal mite trap in this regard. In this concern, the average number of the fallen Varroa mites at the beginning of the experiment (September, 21) was 13.3 and 15.7 in the case of the normal mite trap and the modified mite trap, respectively. These figures increased at the end of the experiment (December 21 ) to 17.3 and 19.7 , respectively.

\section{Discussion}

Varroa mite, $V$. destructor, is the major causal of colony collapse in A. mellifera populations (Rosenkranz et al, 2010).

Table 1 Effect of keeping-bee hives in a dark bee house compared with keeping in bee house with windows and in open apiary on the average number of fallen Varroa mites on white card board sheets as well as on broods and alive bees, during March of 2018 and 2019 at Dakahlia governorate, Egypt

\begin{tabular}{|c|c|c|c|c|c|c|}
\hline \multirow{2}{*}{$\begin{array}{l}\text { Site of } \\
\text { keeping }\end{array}$} & \multicolumn{3}{|c|}{ March 2018} & \multicolumn{3}{|c|}{ March 2019} \\
\hline & Sheet & Brood $^{a}$ & Alive bee $^{\mathbf{b}}$ & Sheet & Brood & Alive bee \\
\hline Dark bee house & $6.2 a$ & $1.2 \mathrm{C}$ & $2.5 \mathrm{C}$ & $6.2 a$ & $1.3 c$ & $2.3 c$ \\
\hline Bee house & $4.3 b$ & $1.8 \mathrm{~b}$ & $5.7 b$ & $4.5 b$ & $2.2 \mathrm{~b}$ & $5.8 \mathrm{~b}$ \\
\hline Open apiary & $2.5 \mathrm{c}$ & $3.2 \mathrm{a}$ & $7.3 a$ & $2.8 \mathrm{c}$ & $3.7 a$ & $8.7 a$ \\
\hline
\end{tabular}

${ }^{a}$ Number of Varroa mite on 20 broods

${ }^{b}$ Number of Varroa mite on 10 alive bees

Duncan multiple range was significant at 0.05 . Means with the same letter are not significantly different. a, b, and c-values in the same column with different superscripts differed significantly 
Table 2 Effect of keeping-bee hives in a dark bee house compared with keeping in a bee house with windows and in open air (beekeeping) on the average number of fallen Varroa mites on while card board sheets as well as on broods and alive bees, during September of 2018 and 2019 at Dakahlia governorate, Egypt

\begin{tabular}{lllllll}
\hline $\begin{array}{l}\text { Site of } \\
\text { keeping }\end{array}$ & \multicolumn{2}{l}{ September $\mathbf{2 0 1 8}$} & & \multicolumn{3}{l}{ September $\mathbf{2 0 1 9}$} \\
\cline { 2 - 7 } & Sheet & Brood $^{\mathbf{a}}$ & Alive bee $^{\mathbf{b}}$ & Sheet & Brood & Alive bee \\
\hline Dark bee house & $24.3 \mathrm{a}$ & $10.8 \mathrm{c}$ & $9.7 \mathrm{c}$ & $28.2 \mathrm{a}$ & $10.3 \mathrm{c}$ & $9.2 \mathrm{c}$ \\
Bee house & $12.2 \mathrm{~b}$ & $21.3 \mathrm{~b}$ & $27.5 \mathrm{~b}$ & $13.5 \mathrm{~b}$ & $22.2 \mathrm{~b}$ & $28.2 \mathrm{~b}$ \\
Open apiary & $11.8 \mathrm{~b}$ & $27.3 \mathrm{a}$ & $40.8 \mathrm{a}$ & $12.2 \mathrm{c}$ & $28.5 \mathrm{a}$ & $42.5 \mathrm{a}$ \\
\hline
\end{tabular}

${ }^{\mathrm{a}}$ Number of Varroa mite on 20 broods

${ }^{b}$ Number of Varroa mite on 10 alive bees

Duncan multiple range was significant at 0.05 . Means with the same letter are not significantly different. $a, b, c-v a l u e s$ in the same column with different superscripts differed significantly

The highest number of the fallen Varroa mites on the white card board sheets was obtained in the case of using of dark bee house during March of both 2018 and 2019, followed by keeping in normal bee house and then those fallen in the case of the open apiary. The same trend was found concerning the number of the Varroa mite on 20 broods and 100 alive bees. Obtained data are in agreement with those reported by Nürnberger et al. (2018) who concluded that timing of brood onset in late winter is mainly driven by temperature but modulated by photoperiod not effect on brood onset.
Rosenkranz et al. (2010) reported that the female of Varroa mites was more likely to lay eggs on drone brood than on worker brood (about 10-12 times). This may be due to drones being of a longer brood cycle. Therefore, this reason inspection of drone brood gives the best chance of detecting the infestation with Varroa mite. In addition, workers brood also reserved as an effective method of detection.

Allo- and auto-grooming contribute to Varroa resistance by both removing mites from adult bees and by physically damaging the mites, preventing them from seeking a new brood cell to infest (Pritchard, 2016).

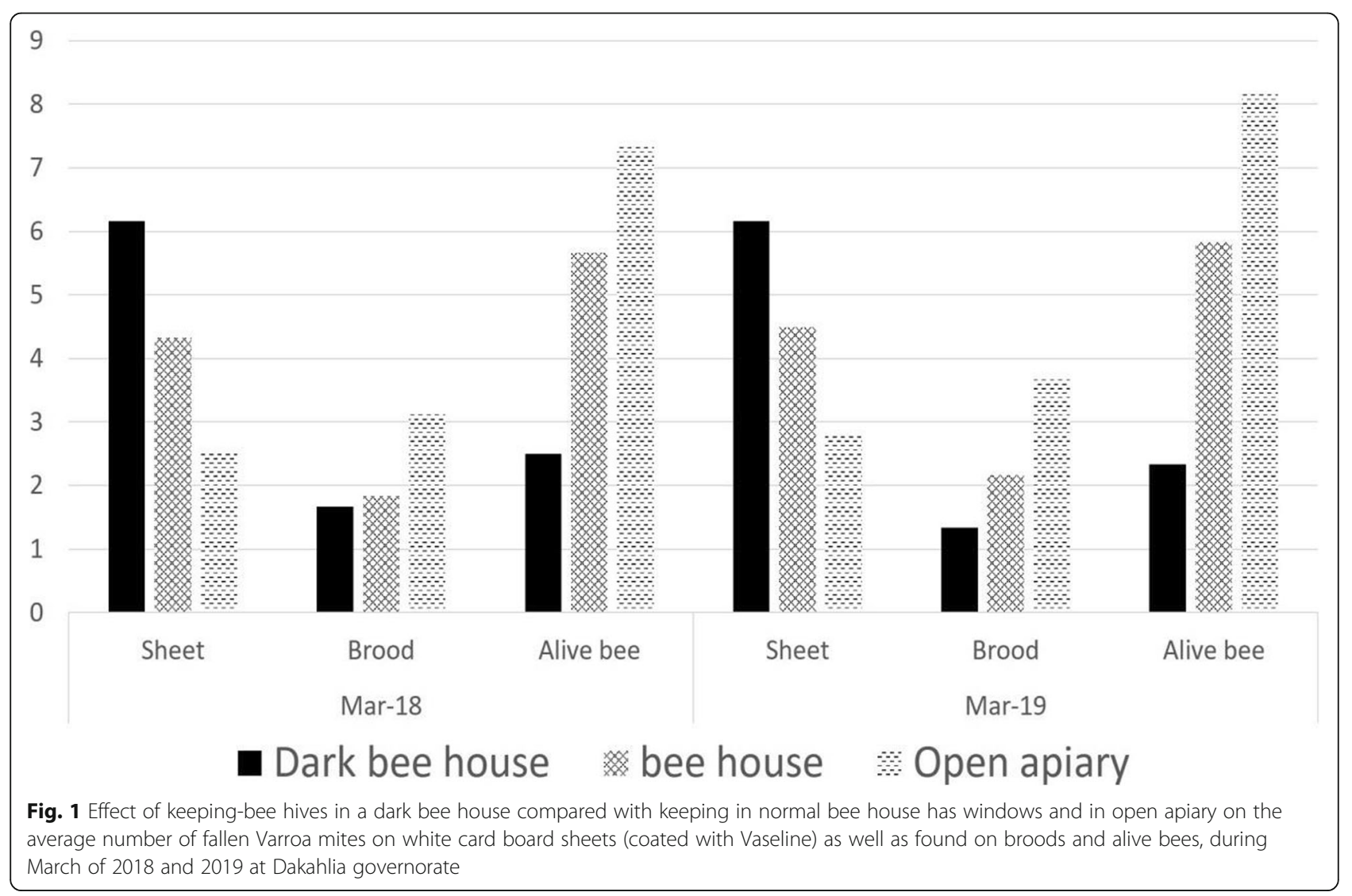




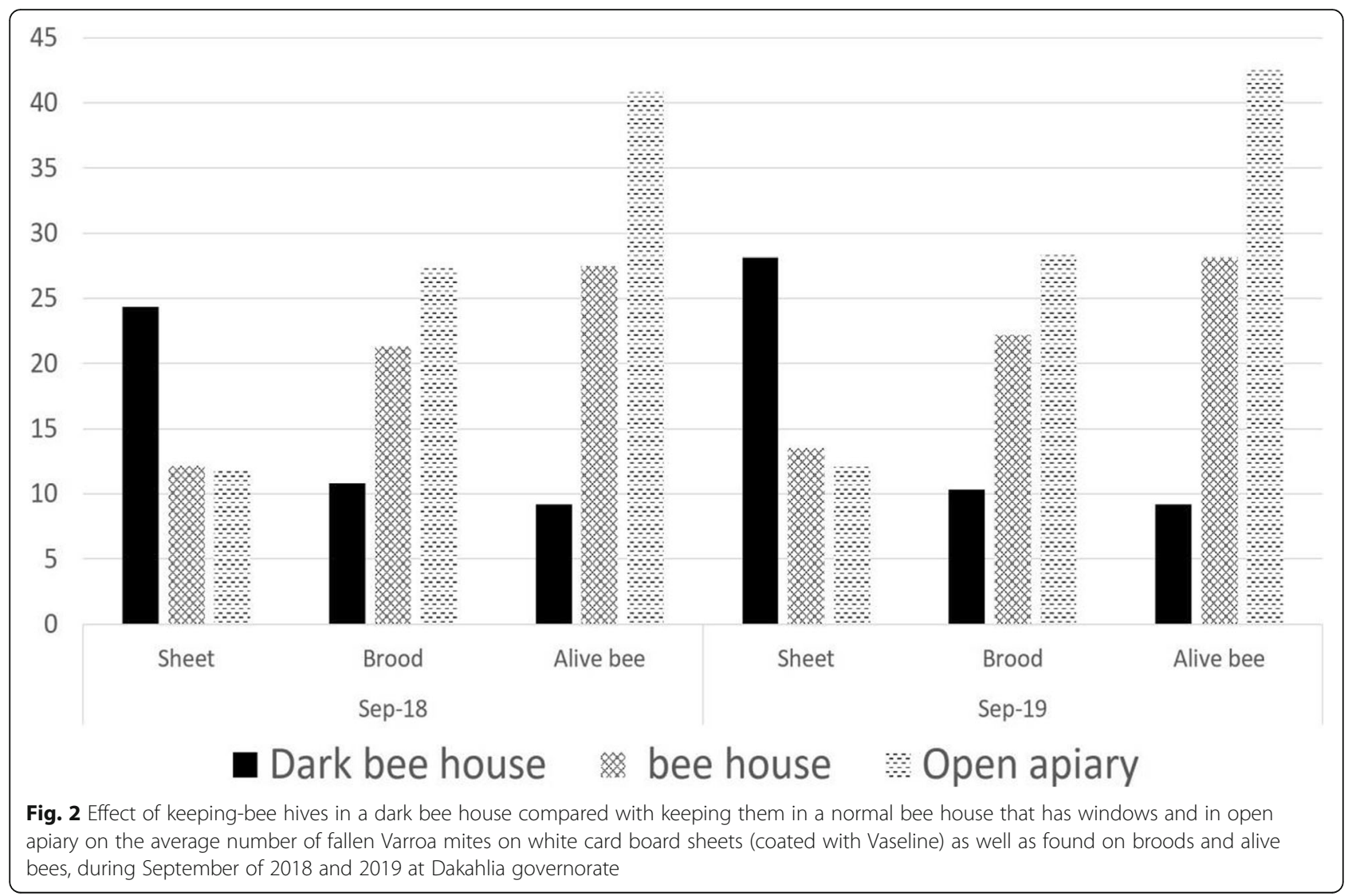

Table 3 Average numbers of Varroa mite fallen on adhesive sheets during September 21 to December 21 of 2019 under bee house conditions at Dakahlia governorate, Egypt

\begin{tabular}{llll}
\hline Date of weekly inspection & Normal mice trap & Modified mice trap ${ }^{\text {a }}$ & Mean \\
\hline 21 Sep & 13.3 & 15.7 & 16.3 \\
28 Sep & 14.7 & 17.0 & 15.5 \\
05 Oct & 15.3 & 17.7 & 16.2 \\
12 Oct & 14.7 & 16.7 & 16.2 \\
19 Oct & 14.7 & 18.0 & 15.7 \\
26 Oct & 14.3 & 18.7 & 16.2 \\
02 Nov & 15.0 & 18.0 & 16.9 \\
09 Nov & 15.0 & 18.7 & 16.5 \\
16 Nov & 15.0 & 18.7 & 16.9 \\
23 Nov & 16.3 & 18.7 \\
30 Nov & 16.7 & 19.7 & 17.5 \\
07 Dec & 17.7 & 19.0 & 17.7 \\
14 Dec & 17.7 & 19.7 & 18.7 \\
21 Dec & 17.3 & 18.0 & 18.5 \\
Mean & 15.6 &
\end{tabular}

aJuice of five broods + royal jelly $(1 \mathrm{~g})$ were spread on each sheet to attract Varroa mite to the sheet L.S.D. at $5 \%$ for date $(D)=1.2$, type of mite trap $(K)=1.4$, and $D \times K=1.9$ 
Honeybees can initiate allo-grooming via a "grooming invitation signal" a whole body vibrational dance lasting several seconds, which stimulates other workers to groom the dancer. Grooming workers use their mandibles and forelegs to forcefully remove the mites from adult bees, leading to mite injury or death (Hamiduzzaman et al, 2017). In the USA, scientists have produced a strain of bees, now commercially available, that exhibit elevated grooming and mite biting (ArechavaletaVelasco et al., 2012).

It has been found that the modified mite trap was more efficient than the normal one for sticking Varroa mites. The number of the conjoined Varroa mites was gradually increased by prolonging the period of the experiment. The increase of the number of the conjoined Varroa mites on the modified mite trap may be due to the volatile substances from brood juice and royal jelly, which attracts Varroa mite to the adhesive sheets and stick them on the sheet. The use of both kinds provides the effort to change the regular sheets every week, as the effectiveness of these sheets last for up to 6 months.

Boecking and Spivak (1999) mentioned that it is commonly thought that bees that vigorously shake and bite the mites are the most efficient groomers. However, this disturbance by the bees may cause the mites to invade brood cells more readily, but this possibility remains to be tested. Likewise, it is thought that colonies that rapidly uncap and remove diseased and parasitized brood are more resistant to diseases and mites.

A study conducted in Mexico identified grooming behaviour as the most important factor that reduces mite population growth in a genetically diverse set of colonies. Colonies that had the lowest mite population growth during an 8-month period exhibited higher grooming behaviour, had higher proportions of chewed mites falling from bees in the colonies, and reduced infestation levels of adult bees (Arechavaleta-Velasco and Guzman-Novoa, 2001).

Tahmasbi (2009) reported that grooming behaviour is considered one of the important mechanisms of honey bee defence against parasitic mites, and affected with genetic characteristics as well as environmental conditions. In addition, Arechavaleta-Velasco and Guzman-Novoa (2001) mentioned that there were two types of grooming behaviour: (1) the removal of foreign objects and pathogens from oneself (autogrooming) and (2) from another adult in the nest (allo-grooming). Moreover, there is a kind of grooming, so-called mite-grooming behaviour associated with higher proportions of mutilated $V$. destructor falling from bees in colonies.

The ability of worker bees to groom other bees may contribute to drone hygiene and health (Hrassnigg and
Crailsheim, 2005),and post-mating changes of the queen (Abdelkader et al., 2014).

\section{Conclusion}

This is the first time dark bee houses were used for selfmanagement or grooming (biologically and/or mechanically) of Varroa mites. Also, replacing the normal adhesive white sheets by adhesive sheets for mite traps kept their efficiency in sticking Varroa mites for more than 4 months instead of 1 week for the normal adhesive white sheets.

\section{Acknowledgements \\ Not applicable}

Authors' contributions

Single author. The author read and approved the final manuscript.

Funding

Not applicable

Availability of data and materials

The review article presented the main aims concluded in the title.

Ethics approval and consent to participate

Not applicable

Consent for publication

Not applicable

\section{Competing interests}

The authors declare that they have no competing interests.

Received: 12 October 2020 Accepted: 8 January 2021

Published online: 23 January 2021

References

Abdelkader FB, Kairo G, Tchamitchian S, Cousin M, Senrchal J, Crauser D, Vermandere JP, Alaux C, Le Conte Y, Belzunces LP, Barbouche N, Brunet J $\mathrm{L}$ (2014) Semen quality of honey bee drones maintained from emergence to sexual maturity under laboratory, semi-field and field conditions. Apidologie 45:215-223

Allam SFM, Hassan MF, Risk MA, Zaki AU (2003) Utilization of essential oils and chemical substances alone or in combination against Varroa mite (Varroa destructor), a parasite of honey bee. Insect pathogens and insect parasitic nematodes, IOBC. Wprs Bull 26(1):273-281

Allam SFM, Zakaria ME (2009) Stimulation effects on the sensory and defensive behaviours of Egyptian honey bees towards Varroa invasion. Acarines 3:2936

Arechavaleta-Velasco ME, Alcala-Escamilla K, Robles-Rios C, Tsuruda JM, Hunt GJ (2012) Fine scale linkage mapping reveals a small set of candidate genes influencing honey bee grooming behaviour in response to Varroa mites. PLOS ONE 7(11):e47269

Arechavaleta-Velasco ME, Guzman-Novoa E (2001) Relative effect of four characteristics that restrain the population growth of the mite Varroa destructor in honey bee (Apis mellifera) colonies. Apidologie 32(2):157-174

Boecking O, Spivak M (1999) Behavioural defences of honey bees against Varroa jacobsoni Oud. Apidologie 30:141-158

Dainat B, Evans JD, Chen YP, Gauthier L, Neumann P (2011) Dead or alive: deformed wing virus and Varroa destructor reduce the life span of winter honeybees. App Environ Microbiol. https://doi.org/10.1128/AEM.06537-11

Danks HV (2002) The range of insect dormancy responses. Eur J Entomol 99:127142. https://doi.org/10.14411/eje.2002.021 [CrossRef] [Google Scholar] Duncan DB (1955) Multiple Range and multiple F-tests. Biometrics 11:1-42

Fries I, Imodorf A, Rosenkranz P (2006) Survival of mite infested (Varroa destructor) honey bee (Apis mellifera) colonies in a Nordic climate. Apidologie 37: 564-570 
Hamiduzzaman MM, Emsen B, Hunt GJ, Subramanyam S, Williams CE, Tsuruda JM, Guzman-Novoa E (2017) Differential gene expression associated with honey bee grooming behavior in response to Varroa mites. Behav Genet 47(3):335-344

Hrassnigg N, Crailsheim K (2005) Differences in drone and worker physiology in honey bees (Apis mellifera L.). Apidologie 36:255-277

Kirrane MJ, de Guzman LI, Whelan PM, Frake AM, Rinderer TE (2018) Evaluations of the removal of Varroa destructor in Russian honey bee colonies that display different levels of Varroa sensitive hygienic activities. J Ins Behav 31: 283-297

Mabrouk AM, Allam SFM, Abada MKA (2016) Rearing honey bee colonies in laboratory for control experiments against Varroa mite in Egypt. Inter J of Sci Eng Res 7(4):2229-5518

Marinelli E, Pulcini P, Margio C, De Pace F, Allegrini F, Persona Oddo L (2004) Oxalic acid by Varrox to Varroa control in Central Italy. Apiacta 39:39-43

Mondet F, Beaurepaire A, McAfee A, Locke B, Alaux C, Blanchard S, Alaux C, Blanchard S, Dank B, Le Conte Y (2019) Honey bee survival mechanisms against the parasite Varroa destructor: a systematic review of phenotypic and genomic research efforts. Int J Parasite 50(6-7):433-447

Neumann P, Carreck NL (2010) Honey bee colony losses. J Apicul Res 49:1-6

Noel A, Le Conte Y, Mondet F (2020) Varroa destructor: how does it harm Apis mellifera honey bees and what can be done about it? Emerg Top Life Sci 4(1):45-57

Nürnberger F, Härtel S, Ingolf Steffan-Dewenter I (2018) The influence of temperature and photoperiod on the timing of brood onset in hibernating honey bee colonies. Peer J 6:e4801. https://doi.org/10.7717/peeri.4801 eCollection 2018

Pritchard DJ (2016) Grooming by honey bees as a component of Varroa resistant behavior. J of Apicul Res 55(1):L 38-L 48

Rosenkranz P, Aumeier P, Ziegelmann B (2010) Biology and control of Varroa destructor. J Invertebr Pathol 103(1):S96-S119

Snedecor GW, Cochran WG (1980) Statistical method, 7th Ed. The lowa State Univ. Press, Amer

Tahmasbi GH (2009) The effect of temperature and humidity on grooming behaviour of honey bee, Apis mellifera (Hym.: Apidae) colonies against Varroa mite, Varroa destructor (Acari: Varroidae). J of Entomol Soc of Iran 28(2):7-23

Ward K, Danka R, Ward R (2008) Comparative performance of two mite-resistant stocks of honey bees (Hymenoptera: Apidae) in Alabama beekeeping operations. J Econ Entomol 101(3):654-659

Yang X, Cox-Foster D (2007) Effects of parasitization by Varroa destructor on survivorship and physiological traits of Apis mellifera in correlation with viral incidence and microbial challenge. Parasitology 134:405-412

\section{Publisher's Note}

Springer Nature remains neutral with regard to jurisdictional claims in published maps and institutional affiliations.

\section{Submit your manuscript to a SpringerOpen ${ }^{\circ}$ journal and benefit from:}

- Convenient online submission

- Rigorous peer review

- Open access: articles freely available online

- High visibility within the field

- Retaining the copyright to your article

Submit your next manuscript at $\boldsymbol{\nabla}$ springeropen.com 